日本臨床外科学会静岡県支部抄録 (静岡県外科医会第231回集談会)

日 時：平成27年 6 月 13 日（土）PM $1 ： 30$ より

会 場: 静岡労政会館 静岡県勤労者総合会館 4 階 展示室・第 3 会議室, 視聴覚室

静岡県外科医会 会長

長 嶋 孝 昌 (北斗わかば病院)

第231回当番幹事

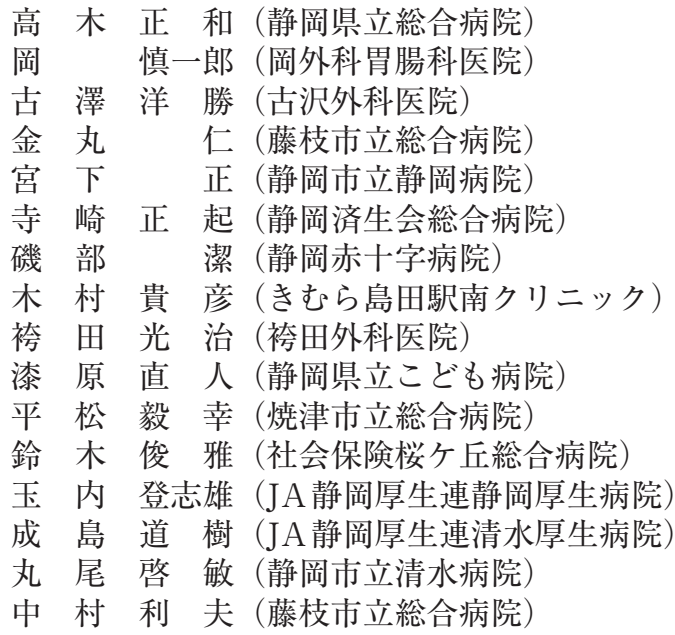

1 胃神経鞘腫の1例

${ }^{1}$ 日本赤十字社浜松赤十字病院外科 ${ }^{2}$ 日本赤十字社浜松 赤十字病院病理

○神谷悠紀 1 、西脇県 1 、代永和秀1、伊藤亮 1 、清野徳彦 1 奥田康一'、安見和彦 2

症例は71歳男性。心窝部痛を主訴に近医より精査目的 で当院へ紹介となった。CTで胃体上部小弯側に長径6.4 cm程の粘膜下腫瘍と \#7リンパ節の腫脹を認めた。上部消 化管内視鏡検査では胃体上部から体下部前壁に5 cm強の 隆起を認めた。EUSでは表面の三層構造が保たれたMPまで 伸展している内部やや不均一の腫瘤であった。以上より、 胃粘膜下腫癔の診断で、腫瘍経が大きく、CT上リンパ節 腫脹も指摘されていたために開腹での㓩部分切除術とリ ンパ節隔清を施行した。病理診断では、\$-100とCD34が陽 性、desminとC-kitは陰性で神経鞘腫と診断された。リン パ節転移は認めず、その他䔡性所見は認めなかった。 胃神経鞘腫は稀な疾患であり、若干の文献的考察を含め て報告する。
富士市立中央病院外科

○一場䍯、蝶野喜彦、武田泰裕、道躭隆行、梶本徹也、 良元和久、坪井一人、北村博影、入村雄也、熊谷祐、 恒松雅、柏木秀幸

症例は40代女性。上腹部痛を主訴に当科を紹介受診した。 4 年前他院で胃癌に対する開腹幽門側胃切除術（RY 再建） を施行されている。上腹部は軽度膨満し、圧痛がみられた。 血液検查で绀资症反応陰性であった。CT榆查で横行結腸に おけるcaliber change掠よび小腸間膜の回転が認められた。 Petersen's hernia にともなら晹閉塞を疑い、緊急開腹手術 を施行した。Y脚吻合部より遠位側の空腸から横行結腸ま での腸管がPetersen's defectに陥入し、腸閉塞に宿ってい た。陥入腸管を引き出し、defectを縫合閉鎖した。総腸間 膜症を合併していたため、小腸だけではなく横行結腸まで defectに迷入したものと考えられた。Petersen's hernia とは、胃切除時のRY再建後に生じる举上空腸と横行結腸間 膜の間隙 (Petersen's defect) に腸管が宿入する内へルニ アである。腹腔鏡手術後の報告は増加しているが、開腹手 術症例では珍しい。自然に整復されることは稀であり、診 断後には早急な手術が推奖される。

3腹腔鏡下に摘出した大網腫瘤（腸管外アニサキ ス症）の1例

静阙市立静岡病院消化器外科

○米沢主、石黑義孝、川口保彦、亶本尚弘、小西大輔、

杉山朋大、上田翔、川守田㤵介、高柳智保、小林敏樹、

橋本洋右、藤本康弘、前田賢人、宮下正

【症例】41嵅・女性。【主訴】上腹部痛・嘔甠。【現症】 上腹部痛・下痱・嘔吐にて発症。2日後当院消化器内科紹介 受診。造影CTにて下行結腸外側に周囲少造影される腫瘤を 認內た。発症5日後加療目的で当科紹介。CT再検すると腫

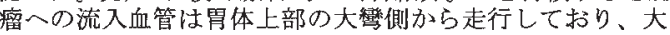
網の腫瘤と考允られた。症状性軽快しており1ケ月後に腹腔 鏡下腫瘍切除を施行した。【手術】胎窝縋切開でE・Z-access を用いて単孔式に行った。左下腹部の大網に $5 \times 2 \mathrm{~cm}$ の腫瘤 を弪めた。腫瘤をLCSにて切除した。経過良好で3 PODに退 院した。【病理】豊富な好酸球と少量の異物型巨細胞を含 んだ肉芽腫に包主れた壊死組織中に、アニサキス幼虫の虫 体を認めた。消化管外アニサキス症と考えられた。【まと め】アニサキス症は中間宿主である鮘やイカを生食攝取す ることによって生じるが、胃ないし腸での発症が多い。当 症例の様に晹管外での発症は比較的まれで、虫体が消化管 を穿通して腹腔内に脱出することで起こるとされる。

ン病の1例

焼津市立総合病院外科 2 焼津市立総合病院消化器内科 3 焼津市立総合病院病理診断科

○北村智恵子 1 、植村祐公 1 、名木田明幸 ${ }^{1}$ 、佐藤沙希 ${ }^{1}$ 、 早阪誠 1 、惟康良平 ${ }^{1} 、$ 本郷久美子 1 、宮戸秀世 1 、 長谷川聡1、北雄介 ${ }^{1}$ 、石原行雄 ${ }^{1}$ 、高林直記 1 、小林亮 1 、 平松毅幸 1 、小平誠 $2 、$ 久権 ${ }^{3}$

症例は42歳、男性。32歳時に大腸型クローン病と診断 され治療を開始した。40歳頃に下行結腸狭窄が強くなり、 42 歳時の3月に大腸閉塞を発症し、内視鏡的バルーン拡張 術を行った。処置後より腹痛が出現し、翌日の精査で、 下行結腸穿孔の診断となる。沉発性腹膜炎の状態であり、 緊急で腹腔内ドレナージ、回腸人工肛門造設術を施行し た。6月に下行結腸狭窄に対して下行結腸部分切除術を行 い吻合は層々吻合で行った。術後経過良好にて7ケ月後 に回腸人工肛門開鎖術を施行した。大腸切除から9ケ月の 現在、維持療法を継続し、再狭窄は認めていない。 
5 急性上腸閒膜動脈塞栓症の1例

藤枝市立総合病院外科

○石津賢一、白川元昭、羽田綾馬、追木宏宣、山中裕太、 五嶋翼、西山元啓、東正樹、岡本和哉、島村隆浩、

姜建宇、前間篤、中村利夫、横山日出太郎、金丸仁

症例は75歳、男性で早朝に下痢を発症し徐々に腹部膨 満感、血便が見られたため当院受診した。

CTにて上腸間膜動脈本幹に大動脈内まで突出するような 形状の血栓を認めた。急性上腸間膜動脈血栓症と診断し、 発症約15時間経過後に血栓摘除術を行った。血流の再開 後腸管の虚血は著明に改善し、腸切除を加えることなく 救命しえた。急性上腸間膜動脈閉塞症仙診断が難しく死 亡率は40～80\%と報告されており、非常に重篤な救急疾 患である。若干の文献的考察を加えて報告する。

\section{6 当院における外傷性萃損傷の検討}

社会福祉法人聖隷福祉事業団総合病院

聖隷三方原病院外科

○高野啓佑、藤田博文、片桐悠介、高井亮、和田侑希子、 上中祐子、丸山翔子、山川純一、前田暁行、木村泰生、 邦本幸洋、荻野和功

外傷性脺損傷は比較的稀であり、重症度診断とそれに 伴う治療方針の決定には難涉する。膵損傷の治療方針の 決定のために、損傷の程度を迅速かつ的確に診断する必 要がある。当院ではCTにて膵損傷を認めた症例に対して、 生命徽侯が安定していればERCP を積極的に施行し、主脺 管損傷の有無を評価している。一方、生命徴候が不安定 な状態では此血処置など生命徽候の安定化を最優先し、 生命徵侯の安定化が得られた後に主脺管の評価を行い治 療法老決定している。今回外傷性脺損傷に対する治療方 針に沿って治療を行った5 例を検討し報告する。

7 乳腺乳頭部腺腫の1例

地方独立行政法人静岡䍗立病院機構静岡県立総合病院乳腺外科

O藤川遼、高柳博行、速水宽介、常泉道子、中上和彦

【はビめに】乳腺乳頭部腺腫は乳頭部に発生するまれな良性腫瘍であるが、

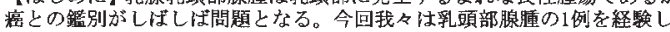
たので若干の文献的考察を加え報告する。[症例】 46歲、女性【主訴] 血 性〜膿性乳頭分泌【蔇往歴・家族歴】特記す心゙きことなし【現病歴】 1 年 程前上り左乳顽から血性一澧性の分泌物を自覚していた。珈りつ汗医を

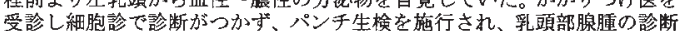

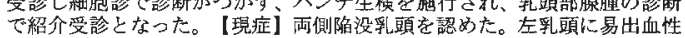

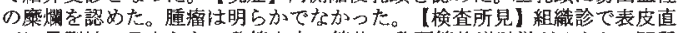
下に異型性の目立たない乳管上皮の管状〜乳頭管状增殖晕がみられ、間貿 增性を伴っていた。腺管の二相性は保たれていた。血液娭查で異常を認め なかった。【手術所見】乳頭を全周性に切開し、螌診で䐈瘤を確認しなが ら切除した。㛟体は交面不整に糜烟化し腫大した乳頭で大きさは $13 \times 18 \mathrm{~mm}$

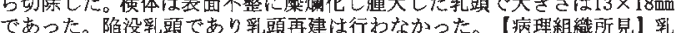
頭内を主座として二層性の保たれた腺管が腺嗹症嵄に線維性間質を伴。 て密在していた。乳頭状充実性の腺上皮の小結節状乳頭腫症も散見された。 腺腫症部分加切雕面に露出していた。CK5/6(+mosaic $), 34 \mathrm{E} 12(+)$, p $63(-$ a few+)【診断】乳頭部腺䏸【術後経過】両側楩没乳頭であり術後の形態 は煡側と比較しても目立たず、経過観察とした。【考察】乳腺乳頭部原腫 は良性上皮性腫宪に分類されるが、組織学的に良悪性の鑑別が難しく、治

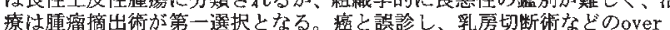

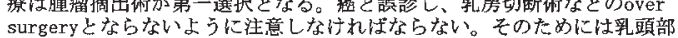

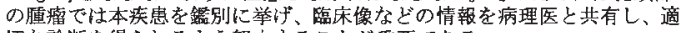
切な診断を得られるよう努力することが重要である。
8 腹膜に発生した坬在性線維性腫瘍の切除後、 再発を認めなかった1例 焼津市立総合病院外科

○名木田明幸、佐藤沙希、早阪誠、北村智恵子、 惟康良平、本郷久美子、宮户秀世、長谷川聡、北雄介、 石原行雄、高林直記、小林亮、平松毅幸、久力権

48歲男性。健診で施行した腹部エコーで膀胱左方に 31 $\times 59 \mathrm{~mm}$ 大の腫瘤を指摘された。CT・MRIでは辺縁平滑で境 界明膫、最大径約 $5 \mathrm{~cm} の$ 充実性腫瘤として描出され、 fibrous tumorあるいはmyogenic tumor 等が疑われた。 腹膜腫瘍切除術を施行し、術所見では左総腸骨'動脈前面 に接する大きさ $6 \mathrm{~cm}$ 、境界明瞭で弾性硬の腫瘤であった。 病理ではSolitary fibrous tumor(SFT)の診断であった。 一般に胸膜外発生のSFTは悪性化率が低いとされるが、長 期経過後の再発も報告されており観察には注意を要する。 本症例はその後再発を認めず5年経過し経過観察中であ る。

\section{9 ハイブリッド手術室を使用した単孔式腹腔鏡} 下腹腔内異物摘出術の1例

静岡市立静岡病院外科・消化器外科

○小林敏樹、川口保彦、高本尚弘、小西大輔、杉山朋大、 石黑義孝、上田翔、川守田啓介、高柳智保、橋本洋右、 藤本康弘、米沢圭、前田賢人、宮下正

症例は、41歳男性。2014年2月に、自転車運転中に転倒 し、左脇腹を打撲。疼痛が持続するため、近医を受診し たが原因学特定できず、痛み此めを処方され経過観察さ れていた。しかし、症状改善を認めなかったため2014年3 月に当院受診となった。腹部単純X線検查および腹部単 純造影CT検查の結果から、腹腔内異物 (針状金属片) が 腹痛の原因と診断し、ハイブリッド手術室において、2014 年4月に単孔式腹腔鏡下腹腔内異物摘出術を施行した。手 術時閒は46分、出血量は1 gであった。術後経過は問題な く、術後1日目に退院となった。今回我々はハイブリッド 手術室を使用することにより、効率的に腹腔内異物を同 定・摘出寸ることに成功した、単孔式腹腔鏡手術の症例 を経験したので若干の文献的考察をふまえて報告する。

10

の1例

S状結腸癌術後に発症したTrousseau症候群

1焼津市立病院外科、2 焼津市立病院外科神経内科、

3焼津市立病院外科病理部

○植村祐公 1 、佐藤沙希 ${ }^{1}$ 、早阪誠 1 、惟康良平 1 、

北村智恵子 1 、本郷久美子 1 、宮戸秀世 1 、長谷川聡 1 、

北雄介 1 、石原行雄、高林直記 1 、小林亮 1 、平松毅幸 1 、

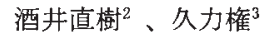

63歳、女性。左側腹部痛、S状結腸腫瘤を主訴に近医 より当科紹介受診。CTにてS状結腸に造影効果のある腫 瘤、腫瘤口側腸管の著明搪張あり、CFでは S 状結腸に全 周性の2 型病変。S状結腸癌によるイレウスと䛦断し、 S 状結腸切除術 (D3) を施行。病理ではtub2、T4N2 (7/15) M0、Stage IIbであった。術後8日目に意識障害、失語が出 現。DWIにて左放線冠に高信号域、MRAにて左中大脳動脈 M 1末梢側以降の血流途絶あり、心原性脳梗塞の診断で 抗凝固療法開始されたが、Holter ECG、心エコーでは心 原性梗塞を示唆する所見はなかった。神経症状は改善し、 32病日、神経学的後遺症なく退院となった。 
11 虫垂杯細胞カルチノイドの1例

藤枝市立総合病院外科

○山中裕太、島村隆浩、羽田綾馬、追木宏宣、五嶋翼、 石津賢一、姜建宇、岡本和哉、西山元啓、東正樹、 前間篤、白川元昭、金丸仁、横山日出太郎、中村利夫 【はじめに】杯細胞カルチノイド（GCC）は生物学的悪性 度が高く、予後不良とされている。本邦で稀とされる虫 垂GCCの一例を経験したため報告する。【症例】53歳、女 性。急性虫垂炎の診断で虫垂切除術を行った。術後の病 理組織学的検討でGCCの診断。虫垂断端に腫凒を認め、リ ンパ管浸潤の報告あり。術後36日日目にD3廓清を伴う、 腹腔鏡補助下回盲部切除術を追加施行した。術後70日目 より補助化学療法施行し、現在、初回手術後12ヶ月経過 し、無再発生存中である。【結語】虫垂炎の診断で手術 施行し、病理組織学的検討により追加切除を要したGCC 症例を経験した。今症例に対して、文献的考察を加えて 報告をする。

12 3群リンパ節転移を来たした S 状結腸SM癌の1例 社会福祉法人聖埭福祉事業団総合病院

聖隷浜松病院

○長谷川悠人、田村俊介、浜野孝、小林靕幸、鈴木一史

【症例】82歳女性。がん検診にて便潜血陽性となりCSにて S 状結腸遠位に15mm大Isp 型腫瘤を認め、SM浸潤が疑われ た。生検ではtub 1が検出された。CTでは明らかな転移を疑 亏所見はなく、腹腔鏡下漓位前方切除＋D2郭清を施行。術 後の病理診断にて、中分化型腺癌十粘液癌、2群りンパ節䡚 移陽性であったことから、術後7日目にIMA根部リンパ節郭 清を追加施行した。3群リンパ節にも転移を認め、T1b, N3, M0, pStageIIIbであった。術後TS- 1による化学療法を行い、 術後1 年で再発なく経過している。【結語】2014年大腸癌 治療ガイドラインでは臨床診断のSM 癌ではリンパ節転移 陽性率梳約 $10 \%$ でほとんどが2 群リンパ節転移までである ため、D2 郭清が推奨されている。本症例では初回手術時 に2群転移陽性であったため3群郭清を追加したところ、こ れも陽性であった。このような広範囲なリンパ節転移を来 たした因子として粘液癌の成分が混在していたことが考え られた。3群りンパ節からも粘液癌成分が検出されていた。 大腸SM癌でも本症例のように広範囲にリンパ節転移を来た すこともあるため適切に対応することが重要である。

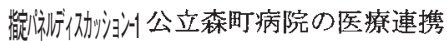

公立森町病院

○中村昌樹

森町の高齢化率は $30.2 \%$ で10年後の全国平均を先取り しています。当院は、これまで在宅医療、介護との連携、 退院支援の強化、回復期リハビリテーション、在宅医療 連携拠点事業、家庭医の養成などに取り組んできました。 隣接市の磐田市立総合病院と業務提携を結び、当院は一 般急性期入院と回復期リハビリテーションを、そして家 庭医療クリニックが外来の専門性を担うことで機能分化 と連携による 3 階建ての医療提供体制を構築してきまし た。昨年度は地域包括々ア病床を稼働させ、地域包括ケ アシステムの中心的役割を担うことを目指しています。 退院支援においては、主治医が退院許可を出した後、細 か、退院調整は専門チームに委称ています。在宅医療に おいては静岡県版在宅医療亦ットワークを、一方医療連 携にはふじのくにネットを活用した2 段構えのITシステ ムの活用を目指しています。以上の取り組みをご紹介さ せていただきます。

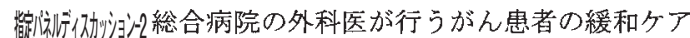
之在宅医潦推進

静岡赤十字病院外科

○白石好

医療経済がひっ迫する中、高齢者の大量死が将来の問 題となる。行政は方策として地域包括ケアを推進してお り、これは病院での治療中心から地域でのQOLを重視する ケアへの転換でもある。死因の多くががんであるため外 科医も余所事ではない。がん患者のQOLのためには診断時 からの緩和ケアが推奖されている。つまり、治療にあた り疾病だけでなく心理、生活といった多面的な視点で患 者を治療、支援していくことが望まれている。そして、 治瘑困難となった患者については看取りを見据えた地域 連携が鍵となる。静岡市がん疾患地域連携協議会 (S-NET) では、2人主治医体制のパートナー診療を基軸にして在宅 看取りのパス化を模索している。静岡赤十字病院外科で は早期加らの在宅隻備を推進しており、入院してからの 退院調整より先に外来通院中から心準備が望ましい亡考 えている。地域連携のスムースな移行のためには、治療 医が率先して淮備開始を担うことが重要である。

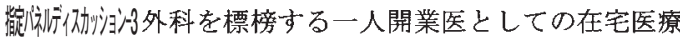
安田クリニック

○安田峯次

在宅医療は、㛜密には、医師や看護師が患者さんの自宅 や生活拠点を訪れて医療を提供することを指すが、広い 意味では医療機関の外来受診で処方された薬を服用する ことまで含まれており、病院医師も、患者個人の生活様 式を念頭に置いた診療を日々行っているはずである。往 診」は、古くから地域医療の定番のアプローチ方法であ り、決して特殊なノウハウが介在する医療の在り方を意 味するものではない。医療費抑制効果が注目されがちだ が、本来は、患者さんが住みなれた御自宅で穏やかな日々 を過ごすことが重要で、実際、癌の末期患者の鎮痛凨の 量が入院患者より少なくてすむことが知られている。当 院では、開院以来6年間で癌や老衰などの末期患者132例 の訪問診療を行い、うち110例の在宅死老見届けてきた。 これらの症例以外にも、病院スタッフとの在宅訪問診療 の適応評㑡に乘離を認識することも度々経験した。外科 を標榜する一人開業医として、在宅医療の課題について 言及したい。

13 腸重積症の1例

磐田市立総合病院外科・消化器外科

○遠藤佑介、稲葉圭介、松本圭五、深澤貴子、宇野彰晋、 北嶋諒、露木肇、清水雄嗣、飯野一郎太、貪野勇記、 鉿木渟司、福本和彦、神藤修、落合秀人、鈴木昌八、 北村宏

症例は77歳、男性。他科通院中に腹痛と黒色便があり、 高度の貧血も認めたため、消化管出血の疑いで入院。上部・ 下部消化管内視鏡検查で異常はなかった。腹部CTで小腸腫 瘍を先進部とする腸重積の状態が指摘された。腫疸は35吅 大で、均一な低吸收值の粘膜下腫瘍であった。超音波検查 ではtarget sign と、先進部の高ココー腫瘤を認めた。重 楮部の腸管には血流と蛙動が観察された。間歇的な消化管 出血と腸重積症を呈する小腸脂肪腫と診断した。入院後は 症状がなく、待機的に手術を行った。腹腔鏡観察で小腸洯 膜面に陷凹部を認めた。肛門側小腸内に腫瘤を榷認して、 病変部腸管を切除した。術後7日目に退院。病理組織学的に も脂肪腫と診断された。病変部の腸管粘膜に潰場形成があ り、消化管出血の原因と考穴られた。成人の小腸重積症は 比較的稀とされ、小腸脂肪腫による成人小腸重積症につい ての文献的考察を加えて報告する。 
14 小腸穿孔で緊急手術を施行したdiffuse

large B-cell lymphomaの一例

1地方独立行政法人静岡県立病院機構静岡県立総合病院消化器セ ンター外科、地方独立行政法人静岡祡立病院機構静岡県立総合病 院病理診断科

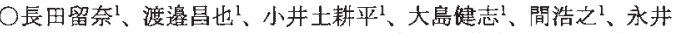
恵理奈 1 、瀧雄介 1 、高橋道郎 ${ }^{1} 、$ 京田有介 1 、佐藤真輔 1 、大端考 1 、 金本秀行 1 、大場範行 1 、高木正和 ${ }^{1} 、$ 鈴木諴 $^{2}$

【症例】64歳女性。発熟と食欲不振、嘔昍を主訴汇近医を受診し、 罱腸炎の診断でその後約2週間フォローされていたが症状改善し ないため、当院紹介受診となった。来院時のCT検査で腹腔内free airを認めた。上部消化管内視鏡検查では穿孔部位を同定できなか つた。消化管穿孔による汎発性腹膜资の診断で同日堅急手術を施 行した。回腸末端から80cmの小腸に狭窄と清演形成を伴う小穿孔 を認め、小腸部分切除術を施行した。組織学的には病变は大型の 芽球様異型リンパ球が粘膜内から㢡膜下にがけびまん性に浸潤 增殖しておう、免疫染色でdiffuse large B-cell 1ymphoma 確定 診断した。術後15日目に退院し、今後原咨㭧に対しての介入をし ていく方針である。【考察】 diffuse large B-cel1 lymphomaは約 半数が節外性で、その中でも消化管が多いとの報告がある。消化 管穿孔をみた場合、消化管原発性悪性リンパ腫についても考慮す るぶきである。

15

穿孔性腹膜炎を来した小腸覀性リンパ腫の1

例

社会福祉法人恩賜財団済生会支部静岡県済生会

静岡済生会総合病院外科

○鈴木瑛、土屋智敬、岡本好史、鈴村潔、西前香寿、

鳥本敦史、添田郁美、寺崎正起

症例は75歳男性。1力月続く黑色便、4kgの体重減少あ り、近医より紹介受信された。腹部造影CTで小腸間膜に 腫瘤を認め、小腸悪性リンパ腫が疑われた。腹腔鏡下生 検を開始したが、腹腔鏡所見より穿孔性腹膜炎が判明し 開腹移行した。腸閒膜全体にリンパ腫様病変あり、後腹 膜八浸潤が認められ、切除は不可能であった。穿孔した 腸管を認め縫合閉鎖したが、腸管切除・人口肛門増設は 困難と考えられ、穿孔部腸管を憩室化し小腸一小腸吻合を 行った。術後小腸一小腸吻合部の通貨障害を認めなかった。 穿孔部より背霊が持続したが経口摄取は可能となった。 生検の結果malignant B cell lymphoma と診断され、現在 当院血液内科にて化学療法中である。

16 鼠径部再発をきたした後腹膜脂肪肉腫の一例 ${ }^{1}$ 浜松医療センター消化器外科 ${ }^{2}$ 浜松医療センター乳腺 外科

○川田三四郎 ${ }^{1} 、$ 西脇由朗 ${ }^{1} 、$ 林忠毅 1 、山下万平 ${ }^{1} 、$

宮崎真一郎1、大菊正人 1 、小泉圭、田村浩章、

平山一久 1 、金井俊和 ${ }^{1} 、$ 徳永祐二 2 、池松禎人 ${ }^{1}$

72歳、男性。腹部エコーで右上腹部から下腹部に達す る腫瘤を指摘され当科紹介となった。画像診断より後腹 膜脂肪肉腫と診断し、手術を施行。病理診断で脱分化を 伴う高分化型脂肪肉腫と診断された。術後 1 年 9 か月後に 施行したCT検査で、右鼠径管の軟部陰影が指摘された。 鼠径へルニアを疑うも手術を希望されず経過観察として いた。術後2年 5 か月後、鼠径部膨隆が増大傾向で、還納 困難であることから鼠径部再発を疑い手術を施行した。 精管近傍に $50 \mathrm{~mm}$ 大の腫瘤を認め、精管由来腫瘍の可能性 も考え精巣も含めて切除した。病理診断で脂肪肉腫の再 発と診断された。脂肪肉腫は四肢と後腹膜に発生するこ とが多く、鼠径部に発生することは稀である。文献的考 察を含め報告する。
17 直腸前方固定術を施行した若年者（完全）直 腸脱の1例

松愛会松田病院大腸肛門病センター

○松田聡、田中荘一、松田保秀、中井勝彦、川上和彦、

木村浩三、野中雅彦、尾田典隆、相川佳子、甲田貴丸

症例は24歳男性。主訴法幼少期少らの下血之脱出。

Ddefecographyにて約 $4 \mathrm{~cm}$ 完全直腸脱を認めた。手術は 下腹部小切開で開腹し、メッシュ (Parietex mesh $\left.{ }^{\circledR}\right)$ を 用いて直腸前壁と仙骨岬角部骨膜老固定した。術後経過 は良好で術後4日目に退院された。当院での若年者直腸脱 の治療について解析し、前方固定術の適応について検 討・報告する予定である。

18 術前診断が困難であった骨盤内腫瘍の一例 社会福祉法人聖赫福祉事業団総合病院 聖隷三方原病院外科

○高井亮、片桐悠介、和田侑希子、上中祐子、丸山翔子、 高野啓佑、山川純一、前田暁行、木村泰生、邦本幸洋、 藤田博文、荻野和功

症例恔37藏、女性。産後1ヶ月検診においてUS で仙骨 前面に長径38ma充実性腫瘤を認めた。腫瘤は造影CTで は造影効果はなく、周囲臟器との明らかな連続性は認め なかった。骨盤内腫瘍の診断にて悪性が否定できないた め腹腔鏡下腫瑒摘出術を施行した。手術所見では、周囲 組織との連続性のない白色鷄卵大腫瘤を認め、そのまま 摘出した。病理組織検查の結果は平滑筋腫であり、子宮 筋腫が自然脱落したparasitic myoma之考えられた。非医 原性のparasitic myomaの報告はほどんどなく、文献的考 察を加えて報告する。

19 臍部毛巣洞の一例

市立島田市民病院

○篠原潤、野村明芳、芦沢直樹、士屋博紀、植田猛、

磯野忠大、盘充弘、木村貴彦、上村和康

毛单洞は仙骨部に好発するが、稀に臍部にも発生し得 る。今回我々は術前診断しえた臍部毛巢洞を経験したた め報告する。症例は38歳男性。臍部からの排膿と疼痛の 主訴で近医受診。抗生昘の投与を受け、症状軽快したの ち、尿膜管遺残の疑いで当院へ紹介された。CT、MRIでは 明らかな氺膜管桽胞は認めなかった。一方、表在エコー では毛巣洞寺唆するエコー像を認め、臍部毛巣洞と診 断。腰椎麻酔下に摘出術を施行した。術中所見で皮下脂 肪組織内に毛髪認めた。病理所見では内部に毛髪を含 部囊胞性病変を認め、毛巣洞として矛盾しない所見が得 られた。術後約半年が経過しているが、現時点では再発 は認めていない。臍部からの排膿という主訴では尿膜管 遺残索疑うことが多いが、まれな腤部毛巣洞も鑑別疾患 の中には含むべきであると考えられた。 
20

縫合系に起因する異物肉芽腫により腸閉塞を 来した 1 例

$J A$ 静岡厚生連遠州病院

○浅井峘るか、鈴木正彦、浅羽雄太郎、三宅隆史、日井 弘明、鶴岡琢也、水上泰延

症例は卵巣癌術後で当院産婦人科通院中の42歳、女性。 強い下腹部痛を主訴に救急外来索受診した。腹部CTで腸 閉塞と診断し、イレウス管による保存的治療により症状 は軽快し退院々なった。退院4日後、腹痛が再燃し救急外 来を再診となった。CT上前回と同様の腸閉塞所見を認め、 再び保存的治療索行ったが改善傾向を認めず、短期間で の症状再然であったため手術適応と判断し開腹手術を施 行した。術中、索状の瘉着を諮め、band 形成による腸閉 塞と診断した。病理検查では索状物は縫合系による異物 肉芽腫との診断であった。非吸収性手術材料はときに晚 期的合併症の原因になることがある。今回我々は、卵巣 癌術後に発生した異物肉芽腫により腸閉塞を来した 1 例 を経験したので、文献的考察をふまえ報告する。

\section{1 右胃大網動脈瘤破裂の1例}

地方独立行政法人静岡県立病院機構静岡県立総合病院外

科

○村木隆太、佐藤真博、永井恵里奈、瀧雄介、渡辺昌也、 大島健志、間浩之、高橋道郎、京田有介、大端考、金本 秀行、大場範行、高木正和

症例は61歳、男性。原発性マクログロブリン血症、ア ミロイドーシス、心房細動にて当院で加療中であった。 腹痛を主訴に当院に受診した。受診時の血液検査で PT-INR 值の過延長と腹部造影CT検查で右胃大網動脈瘤 と同部位からのextravasationを認めた。肝動脈塞栓療法 を施行したが、止血困䨅であったため、緊急手術を行っ た。腹腔内は胃大網動脈に沿って広範な血腫を形成し、 動脈壆の同定は困難であつた。左右大網動脈を結係切離 し、動脈瘤を血腫ごと除去した。術後第13病日で軽快退 院した。病理検査では胃大網動脈に径 $3 \mathrm{~mm}$ の真性動脈瘤を 認め、瘤壁に中膜の粘液変性や弾性板の断裂・消失を認 めた。血管炎やアミロイド沈着所見は認めなかった。今 回、我々は右胃大網動脈瘤破裂に対して手術で救命し得 た1例を経験したので報告する。

\section{2} 切除の1例

独立行政法人国立病院機構静岡医療センター心葴血管外科 ○松本光善、三ッ田翔平、河合憲一、高木寿人、 梅本环也

腹部内臟動脈瘤は比較的まれな疾患であり、部位別頻 度では脾動脈馏が $60 \%$ と最も多い。治療方法には開腹手 術による脾臟合併切除や血管内治療があり、どちらを選 択すべきかコンセンサスは得られていない。われわれは 脾動脈を再建し脾臓を温存した巨大脾動脈瘤切除の1例 を経験したので、若干の文献的考察を加え発表する。症 例は70歳男性、スクリーニング目的のCTで脾動脈瘤を指 摘され当科一紹介された。瘤の最大径は63m民巨大であ つたが症状はなく、待機的に瘤切除術を行うこととした。 腹部正中切開で大網を切開して、瘤の中枢側と末消側の 脾動脈を遮断し瘤を切除した。脾動脈の中枢側と抹消側 を端々吻合し脾臓を温存した。術後ドレーン抜去部の感 染を認めたが軽快し、21日目に退院となった。
23 左腎動脈瘤に対して鏡視下腎摘、ex vivo動脈 瘤切除、自家腎移植を施行した1例

浜松医科大学 第 2 外科血管外科

○矢田達朗、海野宣樹、山本尚人、犬塚和德、佐野真規、 斉藤貴明、杉澤良太、片橋一人、今野弘之

【症例】51歳女性。背部痛を主訴に近医受診した際、偶 然に左腎動脈瘤を指摘され、当科紹介となった。造影CD で左腎動脈本幹遠位から第一分枝にかけて $20 \mathrm{~mm}$ の囊状瘤 を認めた。【手術】まず、右側臥位で鏡視下に左腎を摘 出した。冷却したEuro-Collins液を還流することで摘出 腎を冷阻血状態としてから、Ex vivoで動脈瘤を切除後、 左内腸骨動脈グラフトを用いて腎動脈を形成した。仰卧 位で開腹し、左腸骨窩に摘出腎を移植するべく、動脈は 左内腸骨動脈断端に端々吻合、腎静脈は左外腸骨動脈に 端側吻合、尿管は膀胱に吻合した。【術後】16病日で退 院、腎機能低下は認めていない。【まとめ】鏡視下腎摘 とexvivo動脈瘤切除は低侵襲かつ、腎機能温存の点でも 有用な方法と考える。 